28 May 03 version

\title{
Does Devolution Make a Difference? Legislative Output and Policy Divergence in Scotland.
}

\author{
Michael Keating, Linda Stevenson, Paul Cairney and Katherine Taylor
}

\begin{abstract}
Devolution provides large scope for Scotland to make its own policy. Primary legislation is one measure of this. Scottish legislation before devolution tended to replicate measures for the rest of the UK, with differences of style. Scottish legislation in the first four-year term of the Parliament shows a big increase in output. There is an autonomous sphere, in which Scotland has gone its own way without reference to the rest of the UK. In other areas, there is evidence of joint or parallel policy making, with Scottish legislation meeting the same goals by different means. Finally there is a sphere in which Scottish legislation is essentially the same as that in England and Wales. Sewel motions have not been used to impose policy uniformity on Scotland. There is evidence that devolution has shifted influence both vertically, between the UK and Scottish levels, and horizontally, within a Scottish legislative system that has been opened up.
\end{abstract}

\section{Policy, devolution and legislation}

A key test of the devolution settlement in the United Kingdom is the ability of the devolved institutions to make policy autonomously and, where they wish, to deviate from the line pursued at Westminster. Policy, however, is a notoriously difficult concept to operationalize and measure. Assessing the policy output of an institution can go all the way from looking at general statements of intent to measuring the impact of specific measures on social and economic conditions. In this article we focus specifically on the primary legislative output of the Scottish Parliament during its first term (1999-2003), comparing it with that of Westminster. ${ }^{1}$

The central question is whether devolution has made a difference and permitted Scotland to go its own way. It is complicated by the fact that, unlike other cases of devolution, Scotland has always had its own legal system, with its separate laws, albeit passed by the central parliament at Westminster. Scotland also had its own executive institutions in the form of the Scottish Office, run by a Secretary of State with a substantial bureaucracy in Edinburgh, although these also remained an integral part of the central state government. There are varying interpretations of these old mechanisms for governing Scotland. ${ }^{2}$ Kellas saw them as evidence of a distinct Scottish political system within the British system. ${ }^{3}$ Paterson discerned a pattern of Scottish autonomy based on internal accommodation, although this was stronger at some times than at others and was much reduced by the $1990 \mathrm{~s}^{4}$ Others have tended to see the Scottish arrangements as a way of putting a Scottish face on British policy, and concerned with the details of how things were done rather than what was done. ${ }^{5}$ This is the view to which we adhere. There were occasional innovations like the Social Work (Scotland) Act 1968 and education did 
have its own rather distinct policy community. There was a great deal of policy work and legislation on housing but this tended to follow the main lines of British party policy at any given time. Local government reform was handled separately in Scotland but reforms tended to follow those in England.

Indeed in some fields, Scottish deviations from England were usually due less to the strength of Scottish institutions than to their weakness. Governments are usually hindered more by divisions on their own side than by the Opposition. The weakness of Conservatism in Scotland, including in local government, weakened this factor under the Heath, Thatcher and Major governments, allowing unfettered executive dominance. This allowed for the more radical local government reforms of 1975 and 1996 compared with England. Scottish MPs did carve out their own niche at Westminster, but this was within the boundaries of the British party system and involved modifying the details of policy or lobbying for Scottish material interests rather than forging a distinct policy line. ${ }^{6}$

If this analysis is correct, then devolution does have the capacity to make a difference across two dimensions. Firstly, the Scottish level is more autonomous from London government. Secondly, Scottish interests that could not penetrate the old system of administrative devolution may be better represented, so shifting influence within Scotland. Scotland's new legislative process, with more consultation, and the enhanced role of committees ${ }^{7}$ may allow changes in proposals during their passage. Traditional forms of Scottish distinctiveness on form (the 'how') will remain, but there may be more divergence on substance (the 'what'). On the other hand, there are considerable constraints on policy divergence in practice. ${ }^{8}$ Some are contextual, like the existence of a common British market, a common security area and a welfare state. There are interdependencies between devolved and reserved matters and some devolved matters are highly Europeanized. In many fields, there are common British interest groups and policy communities. ${ }^{9}$ Finally there is the partisan dimension; the first Scottish legislature has been dominated by a Labour-Liberal Democrat coalition not far removed politically from the government in London.

\section{The Division of Powers}

The Scotland Act, 1998, provides for a reasonably clear division of powers between Westminster and the Scottish Parliament by listing only the powers reserved to the centre and leaving everything else in the devolved sphere. Powers which are devolved correspond rather closely to the matters that were previously handled by the Scottish Office, many of which were subject to Scottish legislation. There are, however, some overlaps and interlinked areas, particularly in economic development policy, at the interface between the social security system (reserved) and other forms of social intervention including housing, training and social work, and in criminal justice. While the Scottish Parliament is subject to the ultra vires rule and laws going beyond its powers may be struck down by the courts, no such restriction applies to Westminster, which retains the right to legislate in devolved areas. A convention has been established, however, that Westminster will legislate on devolved matters only with the consent of the Scottish Parliament in the form of a 'Sewel motion'. This has proved contentious. 


\section{General Patterns}

One immediate finding is that the quantity of Scottish legislation increased greatly after devolution. Under the old regime, there was little time for Scottish legislation, although the provisions to take second readings in the Scottish Grand Committee had freed up some time. Between 1979 and 1999 there was an average of six Scottish Acts approved at Westminster per parliamentary session (although there were exceptions for example in 1980 when seventeen were enacted). In the first term of the Scottish Parliament, this had increased to an average of sixteen Acts per session. Some of these involved housekeeping matters for which parliamentary time could not be found before, while others, like the Land Reform Act, were major policy items that had long featured in Scottish political debate.

We can make some overall generalisations from reading Holyrood and Westminster bills together. The Scottish Parliament has taken more care over gender-neutral language and tends to make more reference to consultation procedures. Scottish legislation tends to give more scope to local authorities while Westminster is in the habit of requiring them to draw up specific policy plans as a condition of funding. There is also more of a tendency for Holyrood, through the Subordinate Legislation Committee or the committee processing the bill, to amend bills so as to require committee scrutiny and parliamentary approval for statutory instruments. ${ }^{10}$

Joined-up government appears to be more of a reality in Scotland than in Westminster, with White Papers and legislation keener to draw links between the immediate focus and other policy sectors. For instance, links to health and education issues, which go beyond the most simplistic, are raised in the Transport (Scotland) Act 2001 and Regulation of Care Act 2001. In addition, social inclusion appears to have been 'mainstreamed' to a greater extent in Holyrood legislation than in Westminster legislation, with policies in all areas giving consideration to this issue. All this is consistent with the declared intention of the devolved institution to do politics differently, although it may be a matter of style rather than substance. The tendency to give more scope to local government is consistent with other findings that the Scottish Executive has tended to defer to the strong local government interest within the Labour Party and that relations have not been particularly conflictual. ${ }^{11}$ The one obvious exception is where the Ethical Standards in Public Life etc. (Scotland) Act 2000 provides that the code of conduct for councillors will be determined at national level, where the Local Government Act 2000 enacted at Westminster allows some scope for local adaptation and autonomy, within the parameters set by a model code.

\section{Analysing Legislative Output}

The analysis is limited to primary legislation, although we realise that secondary legislation, administrative devolution and ministerial discretion also influence policy convergence and divergence. Although we have not explored the effects of this, we have sought to indicate areas in which there is scope for further divergence at the secondary level. Accordingly, we have constructed a typology of legislation, going from bills with no counterpart in the other jurisdiction to those that are more or less identical. In between are the categories of bills that deal with the same issue but a different policy and those that deal with the same issue and the same policy. These intermediate categories are 
particularly difficult to analyse, since it is often the details of administrative provision or the scope for statutory instruments and ministerial discretion that will determine whether they really are different. We have therefore pulled out in the analysis the bills that seem to provide such scope. This gives us the following categories.

- Holyrood legislation with no Westminster counterpart

- Westminster Acts with no Holyrood counterpart. We have a separate category here for Sewel motions.

- Legislation that deals with the same issue but with a different policy. This includes similar legislation with significant differences in detail.

- Legislation that deals with the same issue and with the same policy, but with scope for differences in application.

- Legislation that is essentially the same but passed separately

Assigning legislation to individual categories is often a matter of judgement, and the third category in particular merges into the previous one and the next one respectively. Further complications arise from the fact that Acts tend to deal with a bundle of issues in the same policy sector but the particular bundles dealt with in Acts in the two jurisdictions were not necessarily identical. ${ }^{12}$ So we have sometimes categorised individual parts of Acts differently, as well categorising them as wholes. To clarify the purpose and meaning of legislation, we have also looked at White Papers, although these do not always lead to a single Act, but to two or three Acts. For instance, proposals in the DETR's Modernising Social Services White Paper were legislated for both in the Protection of Children Act 1999 and in the Care Services Act 2000. We have also noted substantive policy shifts between the White Paper and legislation ultimately enacted, no doubt following interest group pressure in the two jurisdictions. This was particularly interesting in Holyrood legislation, when White Papers had been published prior to devolution and the Acts passed after it, with shifts in policy showing the greater weight of distinct Scottish interests. The final complication arises from the use of Sewel motions and we have done an analysis of these, to see whether they are being used as an instrument of policy uniformity.

\section{Holyrood legislation with no Westminster counterpart}

We have included thirty eight Acts of the Scottish Parliament in this category. Five deal with public finance: the four annual Budget Acts, plus the Public Finance and Accountability Act 2000. There are also two acts (plus part of another) that ensure Scotland's compliance with the European Convention for the Protection of Human Rights. In fact the Mental Health (Public Safety and Appeals) Act 1999 was the first piece of legislation enacted by the Scottish Parliament and was an emergency measure following a highly publicised court case involving an inmate of Carstairs hospital. This Act, as well as the Adults With Incapacity (Scotland) Act 2000 (addressing advocacy and 
rights issues), served as temporary measures during the completion of the Millan Report. ${ }^{13}$ The subsequent Mental Health (Scotland) Act 2003 was a comprehensive reform of compulsory care and treatment.

The Standards in Scotland's Schools etc Act 2000 and the School Education (Amendment) Act 2002 continue the pre-devolution tradition for Scotland to handle its own education policy, although the former has some overlap with Westminster legislation (see below). Scotland has remained committed to comprehensive education and against opting out of local authority control.

Also included within this category is the highly publicised and politically contentious Education (Graduate Endowments and Student Support) Act 2001, for which there is no counterpart in Westminster. The decision to abolish up-front tuition fees and provide some student grant support in Scottish universities is a clear break with English policy, although the Scottish example was one factor in leading the UK government to propose reintroducing some support in its 2003 White Paper for England. The White Paper's proposals for top-up fees, however, represent a further divergence from Scottish policy. ${ }^{14}$

A further five pieces of Scottish legislation highlight the distinct legislative path in Scotland since devolution, although this sometimes represents convergence with, and some divergence from, English practice. The Land Reform Act introduces possibilities for collective land purchase that have no counterpart elsewhere in the United Kingdom. While in the past Scottish land legislation was passed at Westminster (land reform is an historic aspiration of the Labour and Liberal parties), nothing as extensive as the current Scottish legislation would have found its way onto the Westminster timetable. The Abolition of Feudal Tenure (Scotland) Act 2000 (and its successor, the Title Conditions (Scotland) Act 2003) was a consensual matter long pending. It arguably brings Scotland closer to England, showing that devolution is not just about divergence. The National Parks (Scotland) Act 2000 also implies convergence with England, which has had national parks since the post-war era, when landowner opposition delayed their introduction in Scotland. These latter three Acts highlight the shift in power within Scotland, undermining interests previously sheltered under the old Westminster dispensation.

The Abolition of Poindings and Warrant Sales Act 2001 ends a distinctively Scottish practice, which was widely seen as archaic. Finally, the Protection of Wild Mammals Act 2002 bans hunting with dogs in Scotland. There is no English and Welsh Act due to opposition in the House of Lords but the Bill for England and Wales introduced in 2002 differs significantly in its approach to the issue.

Criminal justice is an area in which Scotland has its own policy community of lawyers, police officers and academics, although there are strong cross-border influences. The division of responsibilities is also such as to make the field particularly entangled. So Scotland has its own Criminal Justice (Scotland) Act 2003 but elements of this follow or prefigure English practices. It was directed against sexual offences and trafficking for prostitution, introduced drug courts and, in its original version, restricted the ability of parents to administer corporal punishment, which would have meant a significant policy divergence from England and Wales. The absolute ban on physical punishment of children under three was removed after parliamentary and media opposition. 
Amendments to provision for non-custodial sentences followed precedents set in England.

There are also several Acts that fit into this category that deal essentially with housekeeping matters and general tidying up that would never have found their way onto the busy Westminster timetable.

\section{Westminster Acts with no Holyrood Counterpart}

One hundred and forty four Westminster Acts have no Holyrood counterpart although twenty eight of these involve Sewel motions where they encroach on devolved matters. Most of these Acts deal with reserved matters and do not concern us here. Thirty six of them do not apply to Scotland, of which eight are for Northern Ireland and one is for Wales. The remainder are England or England and Wales Acts. In addition, there are six Acts that are almost entirely for England and Wales but with some limited Scottish application. Six Acts focusing essentially on criminal justice in England and Wales do not have Holyrood counterparts, and reflect the high place of these questions on the Labour government's agenda at Westminster. Three of these have some Scottish application, showing the entanglement of devolved and non-devolved matters. The Criminal Justice and Court Services Act 2000 applies mostly to England and Wales but some provisions are UK wide: Schedule 5 which amends the Sex Offenders Act 1997; the disclosure by the Secretary of State of driver licensing records; certain provisions relating to the abolition of detention in a Young Offender Institution; and custody for life, and the sections on courts-martial. People disqualified in England and Wales from working with children will also be disqualified from working in Northern Ireland but the extension of this to Scotland was left to Holyrood in the Protection of Children (Scotland) Act 2003 (see below). Courts-martial have jurisdiction across the United Kingdom and this is reflected in the provisions relating to them.

The Health Act 1999 applies to Great Britain and implements Labour policies on health service reorganisation. It has no Scottish Parliament counterpart because it originated before devolution. The Terrorism Act 2000 is UK wide in its application since action on terrorism is a reserved matter. The division of competences here seems a little unclear, since terrorism is presumably defined by the motive of the perpetrator rather than the nature of the deed. It updates existing counter-terrorist legislation (Prevention of Terrorism (Temporary Provisions) Act 1989, Northern Ireland (Emergency Provisions) Act 1996 and sections 1-4 of the Criminal Justice (Terrorism and Conspiracy) Act 1998). The Anti Terrorism, Crime and Security Act 2001, which includes devolved matters, was also adopted on a UK wide basis, with the Scottish Parliament opting into parts of it through a Sewel motion.

There is no evidence that Westminster is using its residual power to legislate in devolved matters at will, or seeking to override the Scottish Parliament. Rather the bills in this category are mostly related to reserved matters, England and Wales matters, and Northern Ireland matters. Sewel motions have been employed in matters that straddle devolved and non-devolved issues. 


\section{UK Legislation with Sewel Motions}

Sewel motions represent a particular category of UK legislation since this trespasses on devolved matters and implies that the Scottish Parliament has surrendered the right to make its own policy. Critics have charged that the number of Sewel motions ${ }^{15}$ breaches undertakings that they would be exceptional, and that Holyrood is surrendering its responsibilities. ${ }^{16}$ More careful analysis, however, reveals a greater complexity. Some Sewel motions stem from convenience, the idea that if Scotland is going to pursue the same policy it need not waste its own legislative time. A good example of this was provided above in the Anti-Terrorism, Crime and Security Bill, 2001, an emergency measure that a Holyrood Bill would largely duplicate. As Deputy Justice Minister Iain Gray argued, a Sewel motion is quicker and more efficient, and it allows the Scottish Executive to legislate selectively. The motive was:

... essentially pragmatic. We do not think it acceptable to delay these matters until the introduction of the Criminal Justice Bill [in Scotland] next year, and we do not think that emergency legislation of our own is appropriate for proposals that are unlikely to differ on either side of the border. It is right to move quickly and, as far as possible, on a common UK front. ${ }^{17}$

This does not mean that Holyrood is surrendering all policy discretion, however, since it can opt out of selected parts of the legislation and bring in its own bill. On the antiterrorism example, the Executive chose not to follow Westminster in three significant issues. While international corruption provisions are excluded because of Scotland's distinct rules of evidence and procedure, the other two opt-outs - relating to policies on racial hatred, as well as new police powers to remove disguises - are policy differences. As Ian Gray explained:

We will pursue a distinctive approach on religious hatred. I shall chair a Ministerial Working Group with cross-party representation and a remit to report by the end of February. The Deputy First Minister has already written to invite the Commission for Racial Equality and $\mathrm{ACPO}(\mathrm{S})$ to participate. We may invite others to participate and will, of course, consult widely if we have decided not to extend to Scotland the new police powers to remove face coverings. The police feel that the benefits would be marginal and largely outweighed by the risk of inflaming already sensitive situations. ${ }^{18}$

A second reason for Sewel motions is to ensure uniformity, and to avoid loopholes, especially in law and order and regulatory matters where the distinction between devolved and reserved matters is not clear. Here there is the prospect of 'regulatory arbitrage' as individuals could exploit differences between the two jurisdictions. ${ }^{19}$ There could in some cases be challenges to the constitutionality of Scottish legislation, where it seemed to be at the boundary between devolved and non-devolved matters, creating a legislative vacuum. The case of the International Criminal Court is a prime example of the need to avoid loopholes. Whilst both Westminster and Holyrood dealt with similar bills and with similar wording, still there was a Sewel motion because the competence of 
the Scottish Parliament to legislate on this matter is open to interpretation (for example, powers of arrest are devolved, but extradition is reserved). The Sewel motion removes doubt by asking Westminster to legislate on the areas with blurred distinctions of responsibility. This looks like a precautionary, pragmatic measure, rather than an instance of political interference.

Similarly, in the case of the Regulation of Investigatory Powers Bills, Jim Wallace argued:

We have been keen to ensure that there are no gaps between the two regimes that could be exploited by those responsible for serious crime, because there is blurred responsibility when the bills require police and law enforcement agency cooperation within Britain. ${ }^{20}$

The same can be said of the Proceeds of Crime Act 2002. The Sewel motion is again required because some areas - drug trafficking, money laundering and taxation - are reserved, whilst other civil and criminal matters are devolved. Jim Wallace argues that the motion reduces the risk of loopholes arising through the separate processes of legislation, since the bill aims to

put drug trafficking and other crimes on to an all-crimes basis.

Comprehensive UK legislation will therefore prove more effective and avoid the risk of inadvertent safe havens on either side of the border. ${ }^{21}$

This concern to avoid loopholes and possible challenges to the constitutionality of legislation means that Sewel motions have been used in criminal and security matters even where Scotland has chosen to legislate separately, as we show below. In these cases, the motions cover matters where there may be some doubt as to whether they are devolved.

Critics have suggested that another reason for using a Sewel motion may be political cowardice, where the Scottish Executive wishes to hide behind Westminster or avoid a public or parliamentary debate. This might be one reason for letting Westminster pass the Sexual Offences Amendment Act after the controversy in Scotland over Section 28/2A. ${ }^{22}$ On the other hand, the Scottish Parliament showed more determination over Section 28/2A than had Westminster, and against more strongly mobilised opposition. In fact, there was a technical reason for letting Westminster regulate here, which is that the original bill was introduced before devolution, in the 1998/9 Westminster session, but defeated in the Lords. The government then proposed to use the Parliament Act to ensure its passage if this was repeated when it was reintroduced. However, this could not be done if the Scottish (or any) provisions were modified before its introduction, since the bill must be identical to the one originally introduced. There is no other evidence that the Scottish Executive or Parliament are getting Westminster to do their unpopular or awkward legislation for them.

Some Sewel motions are introduced not so much to surrender the prerogatives of the Scottish Parliament as to safeguard them, by making the point that the matter in question is indeed in the devolved realm and could be dealt with by subsequent Scottish laws. For 
example, a motion accompanied plans contained in the NHS Reform and Health Care Professions Act because, whilst the health care regulatory bodies come under reserved matters, the Scottish Executive could introduce a new regulatory body which would then come under devolved control. Since no such body existed at the time, the Sewel process could be seen as staking out Holyrood's territory rather than infringing it.

Finally, Sewel motions are used for a variety of administrative reasons, particularly concerning UK regulatory bodies or cross-border matters. The Police Reform Act involved a Sewel motion to allow Scottish police officers to be seconded to the Independent Police Complaints Commission (for England and Wales). The Sewel motion allows a consequential amendment to the Police (Scotland) Act 1967 to safeguard Scottish officers' terms and conditions of service whilst on secondment. Further, as Jim Wallace argues, 'Technically, that is a devolved matter, but it is part and parcel of wider proposals that are not devolved'. ${ }^{23}$

The Care Standards Act involved a Sewel motion to abolish the Central Council for Education and Training in Social Work as part of a move to Scottish regulation. Since the Westminster bill was at a more advanced stage than the Regulation of Care (Scotland) Bill, the opportunity was taken to use it. The Electronic Communications Act does not cover any devolved issues. Rather, it includes provisions for Scottish Ministers to use statutory instruments, rather than primary legislation, to introduce equivalent electronic commerce measures in Scotland, despite this being a reserved matter.

Legislating on banning tobacco advertising followed a rather confusing track. Originally there was to have been UK legislation, and the requisite Sewel motion was passed. This UK bill fell because of the dissolution of Parliament in 2001. This seemed to point to a flaw in the Sewel process, that the Scottish Parliament cannot guarantee that a policy it has endorsed will indeed be carried through at Westminster. Consequently, Nicola Sturgeon (SNP) introduced a separate Scottish Member's Bill. This, although debated in the Scottish Parliament through 2002, was in turn withdrawn at the beginning of December 2002, and single UK legislation enacted with the Sewel motion, the Tobacco Advertising and Promotion Act 2002. Malcolm Chisholm, Deputy Minister for Health and Community Care at the time, explained to the Scottish Parliament in January 2001 that some technical and legal issues might be difficult for Scotland to enforce unilaterally, and some may involve notification to the EU, which would be time consuming. He, therefore, recommended that the Parliament should endorse a single piece of UK legislation, which would take consideration of Scotland's legal system and confer some regulatory and order-making powers on Scottish ministers. As he pointed out:

Advertising and promotional activities do not respect national boundaries. All UK Administrations have a common objective to effect a ban. It is vital to have a consistent approach throughout the UK if the ban is to be effective, robust in the face of any legal challenge and capable of effective enforcement. 24

Not all Sewel motions necessarily encroach on devolved matters. The Limited Liability Partnerships Act dealt mostly with a reserved matter - the regulation of business 
associations, with the Sewel motion addressing the power to make regulations on the process of winding up a limited liability partnership (which is devolved).

There are some real objections to Sewel motions, in that they give Westminster control of the entire legislative process, allowing it to change the original understanding with Scotland. ${ }^{25}$ They may also give powers to Scottish ministers which are not subject to full scrutiny in the Scottish Parliament. There is, however, no evidence that Westminster is abusing the devolution settlement to impose policies on Scotland. Convergence is occurring, where it does, through policy imitation and learning rather than domination.

\section{Legislation that deals with the same issue but with a different policy}

There are eight pairs of Acts that address the same issue but which show significant differences in policy. As these are critical tests of policy divergence, and have proved politically important, we have analysed them individually.

The first two pairs of Acts respond to the demand for something to replace Section $28 / 2 \mathrm{~A}$, which would ban the 'promotion' of homosexuality by local authorities in schools. Repeal in England was blocked by the House of Lords. This creates a policy divergence but not between the elected bodies in the two jurisdictions. In anticipation of repeal, both governments prepared legislation to assuage public concerns, and these show more subtle differences. The relevant clauses are in the Ethical Standards in Public Life etc. Scotland Act 2000 part VI / Local Government Act 2000 section 104, and the Standards in Scotland's Schools etc. Act 2000 section 56 / Learning and Skills Act 2000 section 148. The Scottish legislation places a new duty on councils to have regard to-

a. the value of stable family life in a child's development; and

b. the need to ensure the content of instruction provided in the performance of those functions is appropriate, having regard to each child's age, understanding and stage of development.

It gives no explicit guidance on sex education.

The Westminster legislation, however, stipulates that the Secretary of State must issue guidance designed to ensure that, in sex education, pupils should

a. learn the nature of marriage and its importance for family life and the bringing up of children, and

b. (be) protected from teaching and materials which are inappropriate having regard to the age and religious and cultural background of the pupils concerned.

Differences between these two pieces of legislation are subtle but show Holyrood as being rather more permissive and liberal, despite the strength of opposition to repeal of Section 28/2A.

Another politically salient issue was the decision of the Scottish Parliament, after Henry McLeish became First Minister, to implement the recommendation of the Sutherland report for free provision of nursing and personal care for the elderly in Scotland, which 
the Westminster government declined to do. The relevant legislation can be found in the Community Care and Health (Scotland) Act 2002, which we compare with the Westminster Health and Social Care Act 2001 Part 4 (with Sewel motions). There is also a financial memorandum. This is a clear example of policy divergence, but there are also similarities between the two policies. Both Acts increase the provision of free nursing care. The implementation of the Community Care and Health Act in Scotland results in the delivery of a 'free personal and nursing care ' payment of $£ 210$ per week. Section 49 of the Westminster Health and Social Care Act increases the provision of free nursing care in England and Wales by ensuring that nursing care in certain cases will be provided free of charge by the NHS. Separately from the free care debate, both acts allow for deferred payments of care home fees, with the balance payable on death from sale of assets: land or property.

Local government organisation is a matter traditionally handled separately in Scotland but we have only two rather minor examples - the Scottish Local Government (Elections) Act 2002 and the Local Government Act 2000 part IV. Both deal with local elections, notably their timing. But, while the Holyrood Act seeks to bring local elections into synchronisation with those for the Scottish Parliament, the Westminster Act gives the Secretary of State power to alter, by order, the frequency of elections and the years in which they are held, proposing three possible models. The Holyrood Act makes provision for piloting innovative measures in local elections, especially those designed to improve turnout. Although the Westminster Act omits this, the Modern Local Government White Paper did contain similar proposals for England and Wales.

Water supply matters were also handled separately before devolution, since Scotland's water boards remained public after the sale of water companies in England and Wales. Parts of the Water Industry (Scotland) Bill 2002 and the Water Industry Act 1999 suggest some degree of convergence around a 'new public management' model of service delivery. Scottish Water is to be given greater commercial freedom, restricted as long as its three predecessors remained purely public bodies, while the 1999 Act restricts the abilities of commercial water companies in England and Wales to cut off the water supply following non-payment of charges.

Leasehold reform has long been a preoccupation for Labour governments, but the legal provisions in Scotland differ from those in the rest of the UK to such a degree that the legislation must be quite distinct. So we find in the Leasehold Casualties (Scotland) Act 2001 and the Commonhold and Leasehold Reform Act 2002. These Acts refer to the same broad issue, but are necessarily different in approach because the rules in Scotland were already different. However, the 2002 Act is also more extensive - it addresses major reforms, whilst the Scottish Act is a relatively modest Members' Act to address compensation for leaseholders. The Scottish Act provides for the extinction of leasehold casualties; for the payment of compensation on their extinction; for irritancy provisions in certain leases of land to be void; for the misapplication, in relation to certain leases and the rule of law entitling a landlord in certain circumstances to terminate a lease. The Commonhold and Leasehold Reform Act addresses the problems of leaseholding properties (such as flats) which are interdependent. The commonhold is introduced to give tenants the security of a freehold (which is as close as possible to outright 
ownership) combined with the potential to improve covenants (tying tenants to certain rules of behaviour concerning the upkeep of their property) related to leaseholds.

Marriage is another civil law matter traditionally handled separately in Scotland. The Marriage (Scotland) Act 2002, amends the 1977 Marriage (Scotland) Act to permit civil marriages (since there are no restrictions on religious ceremonies in Scotland) to be solemnised in places approved for the purpose by local authorities or Scottish Ministers. While there is no equivalent legislation in Westminster, the White Paper Civil Registration: Vital Change of January 2002 signals the government's intention to introduce similar legislation (although in England and Wales there are less restrictions on civil and more on religious ceremonies).

In transport, differences have emerged which are at the borderline between differences in policy and differences in application - see, for example, the case of the Transport (Scotland) Act 2001 / Transport Act 2000 parts II and III. In the pre-devolution White Papers ${ }^{26}$ preceding these Acts the overall thrust of policy was the same, but with differences reflecting conditions in the two jurisdictions. In England the key problem is identified as rising car use and the associated problems for the environment, and road traffic. In Scotland, the key issues are Scotland's unique geography, population spread and peripheral position (the last being a trade-related issue). The DETR White Paper emphasises the value of public-private partnerships, while in the Scottish White Paper the emphasis is more on partnership and co-operation between public bodies, especially local authorities. The Scottish White Paper takes integration of transport into other policy areas further than its DETR counterpart. Integration with environmental concerns is understood also to include issues related to heritage, rather than just meeting commitments for reduced $\mathrm{CO}_{2}$ emissions. Integration with education includes the role schools can play in encouraging better transport practices.

Even after devolution, Finance Minister Andy Kerr told the House of Lords Select Committee on the Constitution that the English long-term transport strategy (since largely abandoned) was a relevant framework for Scotland. ${ }^{27}$ This is evident from the subsequent legislation. Both Acts introduce integrated transport strategies in their respective territories. The scope of the Westminster Act is wider, including the reserved matters of air traffic and railways. Otherwise, large sections of the text are the same, with variations reflecting only minor territorial differences in institutional arrangements. A difference reflecting the scope of application is that the Westminster Act places a statutory obligation on local transport authorities to set out local transport and bus strategies. Although they are encouraged to develop and have reference to a coherent transport strategy, no similar statutory obligation is placed on Scottish local authorities. A more substantive difference concerns a shift between the Scottish White Paper and the Act with the disappearance of provision for workplace parking levies and trunk road tolls, although these remain in the Westminster Act. This followed ferocious lobbying of Scottish ministers by the CBI and other business interests. This shows how a policy, which started off in the pre-devolution system, was amenable to change in the new Scottish dispensation. 


\section{Legislation that deals with the same issue and with the same policy, but with scope for differences in application}

Beyond these examples of divergence, the analysis becomes more difficult. The remaining legislation often shows differences in the organisational form of policy, of the sort that existed before devolution. There is also some scope for ministers to implement policy rather differently on both sides of the border. Matters of organisational form and administrative discretion fade into differences of policy, making it difficult to draw clear lines.

Freedom of information is such a borderline issue. It was a salient question in both parliaments and the Scottish Liberal Democrats have made much of the more liberal provision secured by Jim Wallace in the Scottish Act. The basis for both the Freedom of Information (Scotland)2002 Act and the Freedom of Information Act 2000 was the White Paper Your Right to Know (Cm 3818), of December 1997, although the Scottish Executive also published its own consultation document An Open Scotland in November 1999. The wording is slightly different, but the explanatory notes for each Act suggest that these are the same in most part. The Westminster Act stipulates that it does not apply to the Scottish Parliament or Executive or to Scottish devolved bodies (though it does apply in Wales and Northern Ireland). Each act supersedes the existing non-statutory codes of practice on access to governmental information by creating statutory rights of access to a wider range of public authorities (government and Parliament, local government, NHS, educational institutions, the police and other public bodies and offices). The acts cover a general right of access to information held by public authorities, exemptions, the creation of information commissioners, enforcement and a discussion of historical documents. However, the Westminster act also amends the appeals process to the information tribunal dealing with data protection, which is a reserved matter. Both bills were more restrictive than the Labour Party had suggested in opposition, and were further amended during their passage. The Scottish Act is somewhat less restrictive than the UK one, although less so than in its original version. In the Westminster Act, a series of clauses exempts items whose disclosure would prejudice various matters; in the Scottish Act this becomes 'seriously prejudice'. In both Acts there is provision for ministers to disregard notices of failure to enforce if they issue a certificate that enforcement has indeed occurred. Otherwise, in the original versions, only the UK Act gave ministers the last word. A ministerial amendment to the Scottish Act, however, gave a minister the right to disregard the notice if the matter is 'of exceptional sensitivity'. The amendment in turn had been modified in the Parliament to insist on the 'exceptional sensitivity' condition. These differences are subtle but suggest that in practice the Scottish legislation may be rather more liberal than its UK counterpart.

The next set of examples concerns the regulation of public services, according to New Labour philosophy but tailored to the situation in England and Scotland. Policies on access and accountability in the public services have the same aim, but Scotland's circumstances allow its policy to appear more coherent. The Scottish Public Sector Ombudsman Bill 2002 creates one independent ombudsman to be responsible for monitoring all of the listed public services (NHS, local government, housing, mental welfare, enterprise). There is no Westminster legislative equivalent but we compare it with the 1999 White Paper Modernising Government, which introduces a series of 
specific initiatives such as 'Learning Labs' and 'Regulatory Impact Assessments', and lists a series of aims such as NHS Direct being continuously available by 2000 with 'all dealings with Government being deliverable electronically by 2008 '.

Education provides several examples of detailed divergence, for example in the paired Acts, Standards in Scotland's Schools etc. Act 2000 sections 26-31 and the Education Act 2002 Ch 1 of Part 3. Much of the Scottish Act mirrors English trends but with differences of emphasis. Scotland abolishes opting out of local authority control, in line with the general tendency of the Scottish executive to retain the public model of service delivery. ${ }^{28}$ Both Acts deal with school governing boards, but the emphasis in England and Wales is stronger, giving greater devolved powers to governing bodies in maintained schools.

The Scottish Act: 'puts education authorities under a statutory duty to look beyond general provision to the development of the individual child. Authorities will also be required in carrying out their duty under this provision to take account of the child's views when making decisions that would significantly affect them' (para. 6, Explanatory Notes) This increased emphasis on the rights of the individual appears to be in line with trends south of the border. Similarly, the Act's focus on priorities (literacy, numeracy etc.), targets and the measuring of performance seem to mirror developments in this direction at Westminster. However, these are to be determined the Scottish way, via consultation and with parliamentary scrutiny and approval. Section 5 deals with the 'Education Authority's annual statement of improvement objectives', hinting at the type of centralisation and corporate plan-making more readily associated with education south of the border. Parallels with English trends may also be discerned in the Act's provision relating to school development plans, reviews of school performance (which must be published), inspections of education authorities, empowerment of Scottish ministers to issue statutory guidance to education authorities in relation to raising standards and delegation schemes. The abolition of corporal punishment follows the England and Wales example (in the School Standards and Framework Act 1998).

Similarly, the Standards in Scotland's Schools etc. Act 2000 and section 32/ Education Act 2002 part 9 both address the adequate provision for pre-school education. However, the Scottish policy is more concrete and extensive. Whilst the 2002 Act - which amends the School Standards and Framework Act 1998 - requires that LEAs ensure an adequate level of pre-school provision, the Scottish Act also contains provision for local councils to contract this provision out to private nurseries (or at least reimburse parents for a proportion of their private nursery fees).

Another example of different application concerns fuel poverty. The Warm Homes and Energy Conservation Act 2000 requires UK ministers to publish and implement a strategy for reducing fuel poverty (with set targets). This has a Scottish parallel in the 'Central Heating Programme and Warm Deal' policy which states that, 'By 2006 no local authority or housing association tenant or anyone aged 60 or over will have to live in a home that does not have central heating or adequate insulation. ${ }^{29}$ However, during passage of the Housing Bill, the Scottish Executive rejected amendments to make this a statutory requirement.

Examinations are also a matter traditionally organised separately in Scotland. The Scottish Qualifications Authority Act, 2002 amends the Education (Scotland) Act 1996 to respond to the summer exams crisis of 2002 and tends to converge on the English 
Education Act, 1997, Section 21. The Act maintains the board as an Executive NDPB, but reduces its membership from 16-25 to 8-10 including a chair and a chief executive. The membership will be chosen by Scottish Ministers. The SQA will focus on management issues, whilst a new Advisory Body filled by stakeholders will offer advice on qualification issues. This brings the SQA closer to the English Qualifications and Curriculum Authority set up in 1997 which has 8-13 members, all selected by the Secretary of State for Education and Skills.

The regulation of care standards was promised in the pre-devolution White Papers Aiming for Excellence: Modernising Social Work Services in Scotland (March 1999) and Modernising Social Services (DoH, November 1998). Already there were subtle differences, notably in the treatment of local government. Modernising Social Services betrayed a greater distrust of local authorities and a wish to place stricter controls on them. While it suggested that there is currently a conflict of interests in local authorities' roles, the Scottish Aiming for Excellence White Paper only mentioned the potential for a conflict of interests, and the suggestion that local authorities might shirk their responsibilities featured in England but not in Scotland. The DoH White Paper further proposed that payments under the Children's Services Grant be made dependent on the preparation and achievement by local authorities of action plans. The two White Papers gave rise to the Regulation of Care (Scotland) Act 2001 and the Care Standards Act 2000 (which includes a Sewel motion). Both seek to raise social services standards by registering the workforce, establishing new codes of conduct for workers and enhancing professional and training standards, as well as registering organisations and subjecting them to independent scrutiny. They establish bodies with responsibilities in the two key areas of workforce (the Scottish Social Services Council in Scotland and the General Social Care Council in England), and organisational standards (the Scottish Commission for the Regulation of Care in Scotland and the National Care Standards Commission in England). There are, however, some minor differences:

- coverage of the Holyrood Act is broader and includes secure accommodation services, adult placement services, child minding, day care of children and housing support services;

- there are some small differences in the responsibilities of the key institutions, the Scottish Commission for the Regulation of Care, Her Majesty's Inspectors of Schools, the National Commission for Care Standards, the Scottish Social Services Council and the Training Organisation for Personal Social Services (TOPSS) in England;

- there is provision in the Westminster Act for the Care Standards Commission in England to develop a regional structure. Indeed the Modernising Social Services White Paper proposed not the establishment of a National Care Standards Commission, but of 8 regional Commissions;

The Protection of Children Act (1999) requires a list to be kept (by the Secretary of State) of persons considered to be unsuitable to work with children. Such a list was suggested in the White Paper Aiming For Excellence: Modernising Social Work Services in Scotland (March 1999). The Scottish Commission for the Regulation of Care that was, 
in the White Paper's vision, to be responsible for the list, was subsequently established in The Regulation of Care (Scotland) Act 2001. The list itself was only established by the Protection of Children (Scotland) Act 2003. The Scottish Act contains two significant differences. First, the Scottish Executive argued that appeals to the Sheriff Court offered greater protection and less reliance on employer cooperation than the tribunal process established in England and Wales. Second, there is explicit discussion in the Scottish Act on procedures to constrain malicious claims (following an amendment to address the concerns of Michael Russell MSP).

There are similarly detailed but important differences on the question of ethical standards in public bodies, responding to the July 1997 report of the Nolan Committee Standards of Conduct in Local Government in England, Scotland and Wales. The Ethical Standards in Public Life etc. (Scotland) Act 2000 and the Local Government Act 2000 both seek to introduce a new ethical framework for local government, and link their provision to democracy and the 'bond of trust' between bodies and the public. The measures are broadly similar: the introduction of codes of conduct; registers of interests; and clearer independent powers of investigation and adjudication in cases of alleged impropriety. The details of the Acts, however, reveal some important differences in coverage and operation. The coverage of the Holyrood Act is broader, covering all devolved bodies and the code of conduct for councillors (though not for other bodies) is set at national level. In England there is a separation of functions between the local Standards Committees, the Standards Board for England (with a regional structure), and an Adjudication Panel to supply the staff for Tribunals. These functions are combined in the Standards Board for Scotland.

Increased public rights of access to the countryside for recreational use, subject to measures to address conservation, the privacy of individuals and the operational needs of land managers, was promised by Labour before the 1997 election and was realised in the Land Reform (Scotland) Bill Part 1 and the Countryside and Rights of Way Act 2000. The Westminster Act has a greater focus on traffic issues, wildlife enforcement and Areas of Outstanding Natural Beauty. Its provisions on protecting Sites of Special Scientific Interest also apply to Scotland.

Housing is a policy field in which there is a long tradition of separate Scottish legislation, a legacy of distinct institutional arrangements, but also a lot of policy diffusion and mutual learning. This has continued, as we can see from the Housing (Scotland) Act, 2001 and the Homelessness Act, 2002 which both deal with the issue of homelessness in line with Labour policy but in slightly different ways. The Scottish Act also provides for the replacement of Scottish Homes with a new Executive Agency, Communities Scotland. Following the English and Welsh legislation, Scotland then got a dedicated Act on homelessness, the Homelessness (Scotland) Act, 2003.

Finally, the example of commissioners for young people demonstrates a policy convergence fostered by committees of devolved parliaments. The Children's Commissioner For Wales Act 2001 emerged from an Assembly committee. It establishes a commissioner to promote the rights and welfare of young people, and particularly relates to the statutory organizations defined by section 5 of the Care Standards Act 2000. The Education, Culture and Sport Committee sponsored bill Commissioner for Children 
and Young People (Scotland) Act 2003 includes similar provisions to investigate statutory services but also provides for a publicity role to highlight children's rights issues.

\section{Legislation that is essentially the same but passed separately}

Security matters show a large degree of policy similarity, given the common security area and the desire to avoid legal loopholes, despite the devolution of most of the criminal law. So we find a number of Acts that are essentially reproduced separately at Westminster and Holyrood. The Regulation of Investigatory Powers (Scotland) Act 2000 and the Regulation of Investigatory Powers Act 2000 part II (with two Sewel motions) ${ }^{30}$ are identical in large part. Both regulate surveillance and the use of covert intelligence sources. There are some minor differences reflecting the different configurations of institutions and functions north and south of the border. Jim Wallace argued, 'We have been keen to ensure that there are no gaps between the two regimes that could be exploited by those responsible for serious crime, because there is blurred responsibility when the bills require police and law enforcement agency cooperation within Britain. ${ }^{31}$

The International Criminal Court (Scotland) Act 2001 and the International Criminal Court Act 2001 (with a Sewel motion) both give effect to the Statute of the International Criminal Court; provide for offences under the laws of the territories they cover corresponding to offences within the jurisdiction of the Court; enable assistance to be provided to the Court in relation to investigations and prosecutions; make provision in relation to the enforcement of sentences and orders of the Court; and deal with connected purposes. Jim Wallace argued that since the competence of the Scottish Parliament to legislate on this matter is open to interpretation, the Sewel motion removes doubt by asking Westminster to legislate on the areas with blurred distinctions of responsibility. This relates to privileges and immunities, arrest and surrender and the movement of prisoners. $^{32}$

Another pair of Acts that deal with matters at the intersection of devolved and reserved matters are the Education and Training (Scotland) Act 2000 / Learning and Skills Act 2000, and they also have financial implications (sections 104 and 105). The Explanatory Note accompanying the Holyrood Act states that: 'Section 104 of the Learning and Skills Act, which extends to Scotland, provides the Secretary of State with power to specify conditions to be satisfied in order for accounts based on a tied financial product to qualify for the payment of grants. This has been dealt with in the Learning and Skills Act because it relates to the reserved matter of financial instruments. However, powers under section 104 are to be exercisable in, or as regards Scotland, by the Scottish Ministers, subject to the control of the Scottish Parliament'. While the legal provision is the same this gives rather wide scope for administrative variation, analogous to the administrative devolution common in economic and labour market matters. So the different education and qualifications frameworks in Scotland suggest that what is funded may be quite different in practice.

A minor matter but potentially sensitive issue is dealt with separately in the Census (Amendment) (Scotland) Act 2000 and the Census (Amendment) Act 2000. Both enable particulars in respect of religion to be gathered. Scottish ministers had not originally planned such a question, but the Equal Opportunities Commission asked them to do so. 
Since there was widespread support for this in the Scottish Parliament and the relevant committee, the Scottish Executive gave way and converged with England. ${ }^{33}$

The Fur Farming (Prohibition) (Scotland) Act 2002 closes a possible loophole in Scotland opened by the Fur Farming (Prohibition) Act 2000. Fur farming is being banned in England, and the Scottish legislation ensures that the firms based in England and Wales do not just relocate to Scotland. The wording is virtually identical in each Act, with the only difference relating to appeals - to the Crown court in England or Wales and to the High Court of Justiciary in Scotland.

\section{Conclusion}

Legislation is, of course, only one measure of policy divergence and further opportunities for both divergence and convergence arise in its application. Yet we can identify some patterns after four years of devolution. There is a Scottish sphere of legislation on matters not affecting the rest of the United Kingdom, which is considerably larger than before and which does not stem from broader UK initiatives. On the other hand, there is a lot of legislation which is rather similar and shows signs of common origins and principles.

On matters of common interest, there is a large degree of consistency between the Labour-led administrations on both sides of the border but there are differences of style and emphasis. We are also struck by the way in which it is often England that diverges from old policy lines while Scotland chooses not to. This reflects the continued social democratic (or Old Labour as it is rather pejoratively termed) tradition in Scotland as well, perhaps, as the more consultative and consensual policy style, which makes radical policy change more difficult in the short term. Scotland has retained more of the traditional public service model of provision and given a larger role to local government, whether one portrays this, as do some critics ${ }^{34}$ as pandering to 'producer interests' in the public service unions, or as a defence of traditional social democracy. There is also less stress in Scotland on 'targetry', the setting of quantitative targets for policy performance. These differences, albeit matters of degree, go beyond the differences of form visible before devolution.

Coalition government in Scotland has also made a difference. The Freedom of Information legislation is a bit more liberal. There has also been less emphasis on hardline law and order policies, again due to the presence of a Liberal Democrat at the Justice Department. The Criminal Justice Bill for England and Wales introduced in 2002 and which as yet has not counterpart in Scotland provides for curtailment of jury trials; prosecution appeals against judges' dismissal of charges; disclosure of evidence of bad character against the accused; the use of some hearsay evidence; and the possibility of retrial of certain cases and after an acquittal (ending the ban on double jeopardy). The division between the coalition partners in this field was evident during the election campaign of 2003 and Labour's insistence on tougher law and order policies was an issue in the subsequent coalition negotiations in which Labour insisted on new measures and took the Justice portfolio into its own hands.

There is also evidence of common policies turning out differently as a result of differing pressures in the two jurisdictions, as we saw in the Transport Acts. Other divergences, such as the details of access to the countryside, marriage or leasehold reform, represent adaptations to Scotland's legal system and could have been expected before devolution. 
Our analysis also confirms the strong social and contextual pressures to uniformity. The common security area leads to a desire for uniformity on matters of law enforcement and regulation, even while permitting important differences in criminal procedure and rights. Interest group demands also make it difficult to sustain very different levels of social provision on either side of the border. Although we have seen two clear examples in longterm care for the elderly and university fees, these have given rise to demands for parity, with some visible response. The role of the civil service as a unifying force, together with the limited policy capacity of the Scottish Executive, is seen in the tendency to imitative legislation over many fields. There is, however, some scope for initiatives from the devolved assemblies rather than executives and for diffusion around the periphery rather than just from the centre. Both are illustrated by the Commissioner for Children and Young People Act.

Devolution represents an evolutionary process rather than a revolutionary break, with the Scottish Parliament staking out new fields for policy innovation beyond what was available to the old Scottish Office. We have seen evidence of change on both dimensions identified earlier. Scotland does have the ability to go its own way within its devolved sphere, and diverge from law south of the border. There is also some evidence of shift within Scotland, with issues like land reform gaining more prominence. Interest group activity has increased in Scotland ${ }^{35}$ and this can be credited with changes in legislation from White Papers to Acts, although tracing this would require case studies of the passage of individual bills. Some of these measures originated before devolution but were moulded in the Scottish Parliament. The supply of common initiatives will be less in the second Parliament and we may see more divergence again. Where there is a will to make distinct policy, Scotland is able to do so, but the traces of the previous system of unitary government are still highly visible.

${ }^{1}$ The study forms part of a larger project on devolution and policy divergence in the United Kingdom, taking in a variety of measures including expenditure patterns and case studies of specific areas. It is funded by the ESRC programme on Devolution and Constitutional Change.

${ }^{2}$ Michael Keating 'Scottish Autonomy, Then and Now', Scottish Affairs, special issue (2001), pp.91-103.

${ }^{3}$ Kellas, James The Scottish Political System, $3^{\text {rd }}$ edn., Cambridge: Cambridge University Press, 1984,.

${ }^{4}$ Lindsay Paterson, The Autonomy of Modern Scotland, Edinburgh: Edinburgh University Press, 1994.

5 James Ross, 'The Secretary of State for Scotland and the Scottish Office', Studies in Public Policy, 87, Glasgow: University of Strathclyde1981). Arthur Midwinter, Michael Keating and James Mitchell, Politics and Public Policy in Scotland, London: Macmillan, 1991. 
${ }^{6}$ Keating, Michael, The Role of the Scottish MP, PhD thesis, Glasgow College of Technology and CNAA, 1975.

${ }^{7}$ David Arter, 'On Assessing Strength and Weakness in Parliamentary Committee Systems: Some Preliminary Observations on the New Scottish Parliament', The Journal of Legislative Studies, 8.2 (2002), pp.93-117..

${ }^{8}$ Keating, Michael, 'Devolution and Public Policy in the United Kingdom: convergence or divergence?', in John Adams and Peter Robinson (eds), Devolution in Practice. Public Policy Differences within the UK, London: Institute for Public Policy Research, 2002.

${ }^{9}$ Michael Keating and John Loughlin, 'Territorial Policy Communities and Devolution in the United Kingdom', European University Institute Working Papers, SPS 2002.1, Florence: European University Institute, 2002.

${ }^{10}$ Mark Shephard, and Paul Cairney, 'Does the Scottish Parliament Matter?', Paper at the Annual Meeting of the American Political Science Association, 29 August- 1September, 2002.

${ }^{11}$ Michael Bennet,, John Fairley and Mark McAteer, Devolution in Scotland: The impact on local government, London: Rowntree Foundation, 2002.

${ }^{12}$ Thus, for example, the Standards in Scotland's Schools etc. Act 2000, taken as a whole had no counterpart in Westminster legislation. However, certain sections of it did have counterparts in sections of Westminster legislation - the Learning and Skills Act 2000 and the Special Educational Needs and Disability Act 2001. Similarly, taken as a whole, these two Acts had no counterpart in Holyrood legislation, but two further sections of the Learning and Skills Act were the subject of an entire Holyrood Act, the Education and Training (Scotland) Act 2000.

${ }^{13}$ New Directions - Report on the Review of the Mental Health (Scotland) Act 1984 (January 2001) http://www.scotland.gov.uk/health/mentalhealthlaw/Millan/Report/rnhs00.asp

${ }^{14}$ The White Paper proposes top-up fees, for which there is almost no support in Scotland. If the Scottish Parliament were to decide not to adopt them, Scottish universities would have to get more public funding or be at a disadvantage.

${ }^{15} \mathrm{Up}$ to 20 March 2003 there were forty motions passed (and one withdrawn), covering thirty six bills. Seven of these bills were still in progress following the end of the first Scottish parliamentary term.

${ }^{16}$ Gerry Hassan, 'Scotland's Copycat Parliament', The Herald, 2 September 2002. Alan Page, Memorandum and Evidence, House of Lords Select Committee on the Constitution, Devolution: Inter-Institutional Relations in the United Kingdom, Evidence complete to 10 July 2002, HL 147, pp.183-6. Alan Page and Andrea Batey, 'Scotland's Other Parliament: Westminster Legislation about Devolved Matters in Scotland since Devolution', Public Law, Autumn 2002, pp.501-23.

${ }^{17} \mathrm{http}: / / \mathrm{www}$. scotland.gov.uk/pages/news/2001/11/SE4359.aspx.

${ }^{18} \mathrm{http}: / /$ www.scottish.parliament.uk/official_report/session-01/sor1115-02.htm\#Col3839.

${ }^{19}$ Page and Batey, 'Scotland's Other Parliament'.

${ }^{20}$ (http://www.scottish.parliament.uk/official_report/session-00/or051402.htm\#Col1462).

${ }^{21} \mathrm{http}: / /$ www.scottish.parliament.uk/official_report/session-01/sor1024-02.htm)

${ }^{22}$ Page and Batey, 'Scotland's Other Parliament'. 
${ }^{23} \mathrm{http}$ ://www.scottish.parliament.uk/official_report/session-02/sor0130-02.htm.

24 (http://www.scottish.parliament.uk/official_report/session-01/or100302.htm\#Col274)

${ }^{25}$ House of Lords Select Committee on the Constitution, Session 2002-3, Second Report, Devolution: Inter-institutional Relations in the United Kingdom, HL 28, 2003).

${ }^{26}$ Travel Choices for Scotland: The Scottish integrated transport white paper (presented to Parliament by the Secretary of State for Scotland, July 1998) and A New Deal for Transport: Better for Everyone (DETR, July 1998

${ }^{27}$ Andy Kerr, Oral evidence to House of Lords Select Committee on the Constitution, 16 May. 2002. Memorandum and Evidence, House of Lords Select Committee on the Constitution, Devolution: Inter-Institutional Relations in the United Kingdom, Evidence complete to19 July. 2002, HL 147, pp.158-65.

${ }^{28}$ Keating, 'Devolution and Public Policy in the United Kingdom.'

${ }^{29} \mathrm{http}: / / \mathrm{www}$. scotland.gov.uk/pages/news/2002/10/sesj067.aspx

${ }^{30}$ The Sewel motions relate to: (1) the operations of UK law enforcement bodies like HM Customs and Excise operating in Scotland, with the understanding that the Scottish legislation will only cover bodies when there is no doubt about their devolved competence; (2) the coverage of the interception of communications by law enforcement agencies; (3) setting up special tribunals for redress following investigations covered by these bills.

${ }^{31}$ (http://www.scottish.parliament.uk/official_report/session-00/or051402.htm\#Col1462

${ }^{32} \mathrm{http}: / / \mathrm{www}$. scottish.parliament.uk/official_report/session-01/or100402.htm

${ }^{33} \mathrm{Jim}$ Wallace, Oral evidence to House of Lords Select Committee on the Constitution, 16 May, 2002. Memorandum and Evidence, House of Lords Select Committee on the Constitution, Devolution: Inter-Institutional Relations in the United Kingdom, Evidence complete to 19 July. 2002, HL 147, pp.166-71.

${ }^{34}$ Gerry Hassan and Chris Warhurst, 'Future Scotland', in Gerry Hassan and Chris Warhurst (eds), Tomorrow's Scotland, London: Lawrence and Wishart, 2002. Hassan and Warhurst, from a New Labour perspective, also chide the main opposition party in Scotland for sharing the old consensus. 'The SNP has adopted a set of assumptions and beliefs that social democratic parties the world over are moving away from: the government and the state are good; that the public sector always works as a force for progress; that public spending is always a virtue...defining vested interest Scotland as the voice of the people' p.8.

${ }^{35}$ Keating and Loughlin, 'Territorial Policy Communities'. 